\title{
Reconstruction of Paleovegetation and Paleoecology from the Early Cretaceous Sporomorphs of Bougaz-1 well, northeast Sinai, Egypt
}

\author{
Zainab M. El Noamani \\ Botany Department, Faculty of Science, Ain Shams University, Cairo, Egypt.
}

\begin{abstract}
A WELL-preserved, diverse sporomorph assemblage of 62 species belonging to 39 genera has been recorded in two Cretaceous (Aptian/Albian) samples recovered from depths $3105 \mathrm{~m}$ and $3117 \mathrm{~m}$ in the Bougaz- 1 well, northeast Sinai. The identified 62 species consist of 20 genera and 27 species of pteridophytic fern spores, nine genera and 15 species of gymnosperm pollen, and 10 genera and 20 species of angiosperm pollen. A correlation of the encountered sporomorphs and their parent plant affinities (classes, orders and families) has been attempted in order to give an image of the past vegetation in this part of Egypt. Vegetation reconstruction demonstrates a mixed forest which is represented by a mixture of ferns, gymnosperms and angiosperms. A remarkable abundance of pteridophytic fern spores with other hygrophilous elements such as Afropollis pollen seems to indicate paleoclimatic trends towards warm humid conditions during the Aptian/Albian period in the studied area. This climatic preference is also confirmed by the low frequencies of conifer vegetation such as Araucariaceae, Cheirolepidiaceae and genetalean pollen (Ephedripites) which were predominant on the topographically higher and relatively xeric environments.
\end{abstract}

Keywords: Aptian/Albian, Cretaceous, Egypt, Paleoecology, Paleovegetation, Sporomorphs.

\section{Introduction}

The Cretaceous deposits are widespread in different basins and sub-basins in the surface and subsurface of Egypt and are considered one of the main targets of oil exploration by the drilling companies (Abdel-Kireem et al., 1996). Because of this economic value, these strata are the scope of interest of many researchers mostly with regards to seismic, lithostratigraphy, sedimentology, geochronology and biostratigraphy.

From the botanical point of view, the Cretaceous was an important period in the history of the plant kingdom. Differences between Early Cretaceous and Late Cretaceous floras are much more pronounced than those between Late Jurassic and Early Cretaceous or between Late Cretaceous and Paleocene floras. The Early Cretaceous floras dominated by the ferns and gymnosperms over the angiosperms which started to appear by the end of the Jurassic and the beginning of the Cretaceous. In contrast, all Late Cretaceous floras are dominated by angiosperms, and consisted largely of modern families. Even the ferns, of which many are known, have modern analogy. The majority of the older cycadophytes, ginkgophytes and conifers had disappeared during the Late Cretaceous (Arnold, 1969).
Cretaceous sporomorph assemblages from Egypt and north Africa are of interest. During the Cretaceous period, especially the Early Cretaceous, Egypt and surrounding areas were part of a broad, low latitude belt that played an important role in the initial radiation and diversification of the non-dominant angiosperms (Schrank \& Mahmoud, 2002). Many papers have been published on the palynology of the Egyptian Cretaceous strata since the pioneering works by Saad (1963, 1965, 1974 and 1978). Most of these works are more inclined towards biostratigraphy and geochronology, but few tackled how fossil miospores can be used to imagine the distribution, diversification and ecology of our earliest terrestrial floras.

This paper is a continuation of the study of the terrestrial palynomorphs from the Cretaceous sequence in Bougaz-1 well, northeast Sinai (El Noamani \& Saleh, 2018). The latter work was restricted to the algal palynomorphs and excluded the diverse pollen and spores assemblage studied in the present work. The main goal of this study is to use the overall composition of the encountered miospore assemblage to configure a tentative picture for the paleovegetation model and more precise interpretation of the Aptian/Albian palaeoclimatic conditions which prevailed in 
that part of northeast Sinai. To conduct such interpretations, semi-quantitative analysis of all miospore taxa and their possible parent plant affinities of miospore genera encountered in the present study are made.

\section{Material and Methods}

This study is based on the investigation of two cutting samples taken at depths $3105 \mathrm{~m}$ and $3117 \mathrm{~m}$ from the Aptian/Albian sequence encountered in Bougaz-1 well (Fig. 1). The samples consist of greyto brown soft clay. Samples were processed for palynological study as follows: $10 \mathrm{~g}$ of each crushed sample were treated with 10\% HCL, $40 \%$ HF, 39\% HCL, Zinc chloride solution (specific gravity: 1.9), $10 \% \mathrm{HCL}$ and finally sieving with a nylon filtering screen $(15 \mu \mathrm{m}$ mesh). Two permanent slides per sample were prepared using DPX as mounting medium. Using light microscopy, two slides of each sample were completely scanned and the observed miospores were identified to the lowest taxonomic level possible. The semi-quantitative analysis was based on the first 200 miospores (spores and pollen grains) counted on each slide. The specimens of interest were photographed using a Canon PowerShot G12 digital camera attached to a DEL binocular biological compound microscope and illustrated in Plates I, II and III. The locations of the illustrated specimens on the microscope slides are given as England Finder coordinates. The prepared slides and the remaining residues are housed in the palynological collection at the Paleobotany and Palynology Lab, Botany Department, Faculty of Science, Ain Shams University, Egypt.

\section{Results}

In the present analyzed material 62 miospore species have been identified including 27 species of ferns, 20 species related to the angiosperm pollen, meanwhile the gymnosperms are the least representative component which are represented by 15 species.

The present study uses a systematic organization of miospore genera that is formalized to suit the botanical affinities of the encountered taxa to reconstruct the paleovegetation based on the available data obtained from Couper (1958), Brenner (1963), Dettmann (1963), Singh (1964, 1971), Felix \& Burbridge (1973), Srivastava (1977), Wingate (1980), Kedves (1986), Takahashi \& Sugiyama (1990), Srivastava \& Binda (1991), Mohr \& Gee (1992), Ravn (1995), Dino et al. (1999), Abbink et al. (2004), Mahmoud \& Schrank (2007), Narváez \& Sabino (2008), Pole \& Vajda (2009), Scafati et al. (2009), Krassilov \& Schrank (2011), Villalba-Breva et al. (2012) and Ibrahim et al. (2017), as outlined in Table 1.

\section{Paleovegetation reconstruction}

The Aptian/Albian palynoflora in Bougaz Basin comprises a variety of plant groups. Information on the botanical affinities of the principal dispersed spore and pollen genera or categories in the studied samples is summarized in Table 1. In general, the vegetation in this interval is interpreted as a mixed forest which is represented by a mixture of ferns, gymnosperms and angiosperms. Their variations in dominance apparently influenced the overall structure of the vegetation.

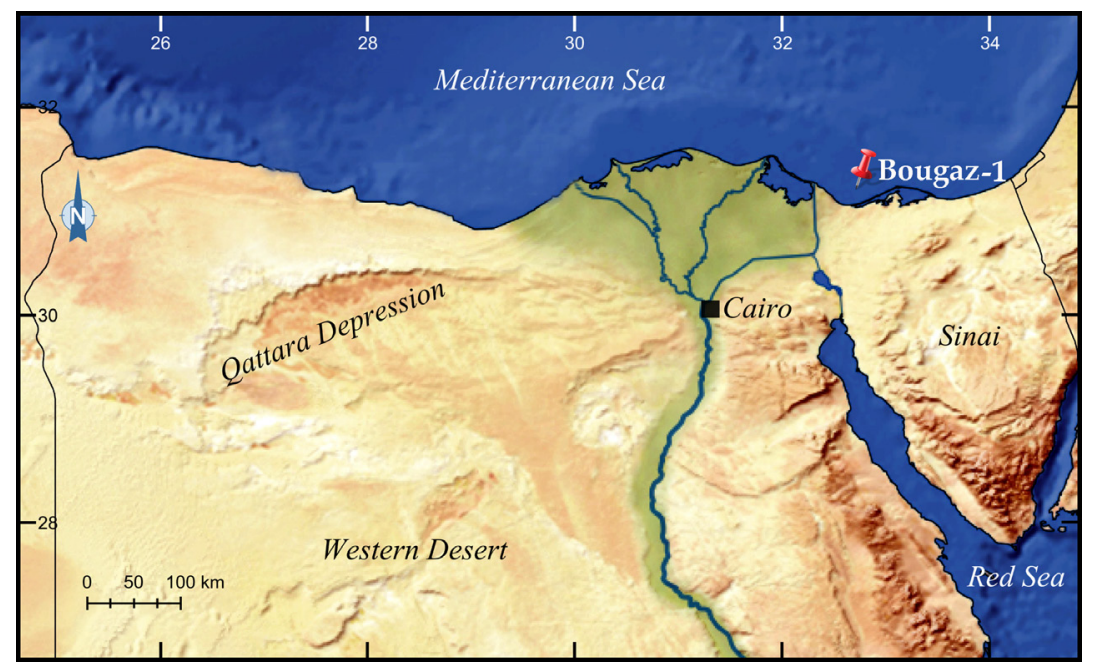

Fig. 1. Location map of Bougaz-1 (B-1) well (after EI Noamani \& Saleh, 2018). 


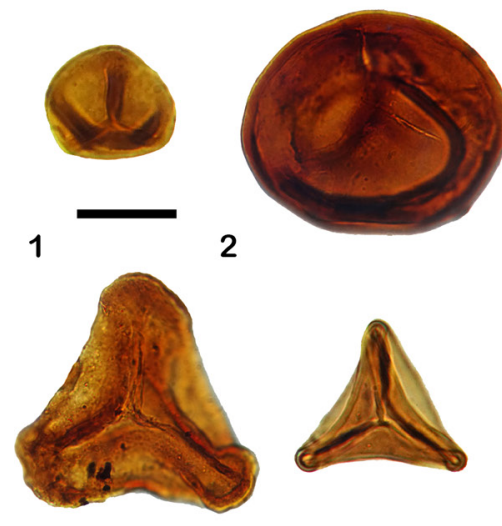

5

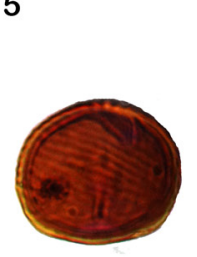

9

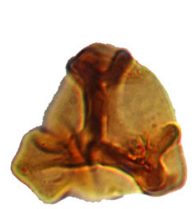

13

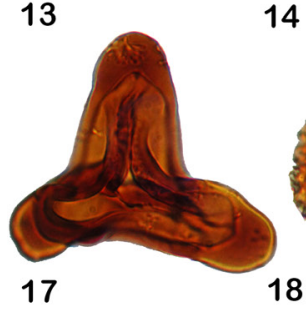

6

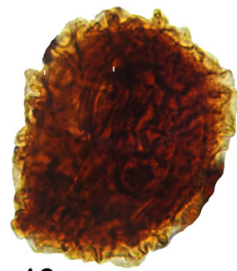

10

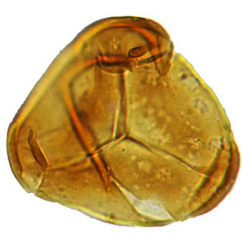

14

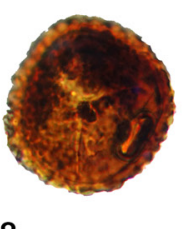

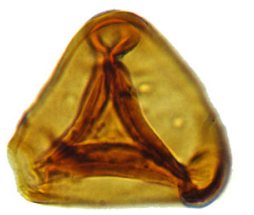

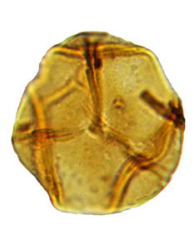

11

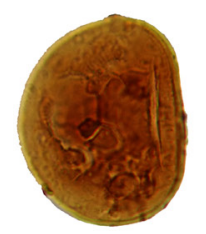

15

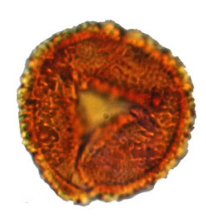

19
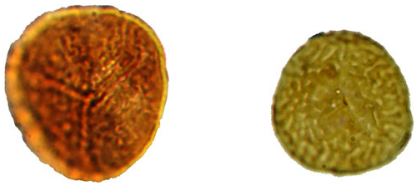

4

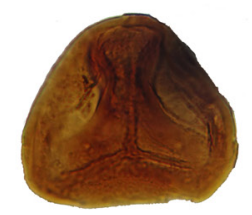

8

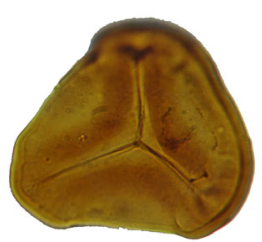

12
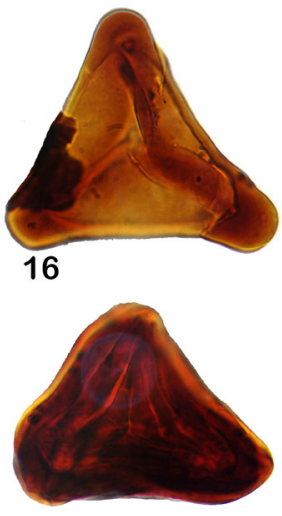

20

Plate I.

I.1 Biretisporites potoniei Delcourt and Sprumont; B-1 3117/1; M19/2-4; $17 \mu \mathrm{m}$.

I.2 Punctatisporites couperi Ravn; B-1 3117/1; J34/2; $26 \mu \mathrm{m}$.

I.3 Punctatisporites globosus (Leschik) Lund; B-1 3105/1; B55/2-4; $15 \mu \mathrm{m}$.

I.4 Rugulatisporites sp.; B-1 3105/4; T44/3-4; $20 \mu \mathrm{m}$.

I.5 Gleicheniidites senonicus Ross; B-1 3105/1; E16/2; $26 \mu \mathrm{m}$.

I.6 Gleicheniidites sp.; B-1 3117/1; Y14/1-3; $21 \mu \mathrm{m}$.

I.7 Dictyophyllidites equiexinus (Cookson) Dettmann; B-1 3117/3; M63/1-2; $21 \mu \mathrm{m}$.

I.8 Dictyophyllidites harrisii Couper; B-1 3105/1; Q20/2-4; $23 \mu \mathrm{m}$.

I.9 Cicatricosisporites minutaestriatus (Bolkhovitina) Pocock; B-1 3105/1; H44/2-4; $20 \mu \mathrm{m}$.

I.10 Crybelosporites pannuceus (Brenner) Srivastava; B-1 3105/2; N53/1-3; $23 \mu \mathrm{m}$.

I.11 Cibotiumspora juncta (Kara-Murza) Singh; B-1 3105/1; L44; $19 \mu \mathrm{m}$.

I.12 Deltoidospora australis (Couper) Pocock; B-1 3105/2; J17/2; $22 \mu \mathrm{m}$.

I.13 Cibotiumspora jurienensis (Balme) Filatoff; B-1 3105/2; P30; $15 \mu \mathrm{m}$.

I.14 Deltoidospora sp.; B-1 3105/2; Q31/1; $22 \mu \mathrm{m}$.

I.15 Laevigatosporites sp.; B-1 3105/2; S22/2; $20 \mu \mathrm{m}$.

I.16 Trilobosporites laevigatus El-Beialy; B-1 3105/2; G19; $24 \mu \mathrm{m}$.

I.17 Trilobosporites laevigatus El-Beialy; B-1 3105/2; R40/3; $22 \mu \mathrm{m}$.

I.18 Verrucosisporites rotundus Singh; B-1 3105/2; B54/1-3; $19 \mu \mathrm{m}$.

I.19 Dictyotosporites sp.; B-1 3105/2; L43/1;20 $\mu \mathrm{m}$.

I.20 Duplexisporites generalis Déak; B-1 3117/1; R44/1-3; $20 \mu \mathrm{m}$. 


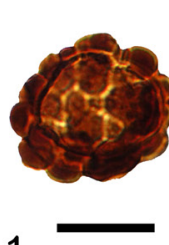

1

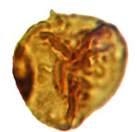

5

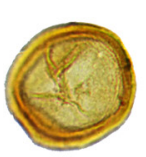

9

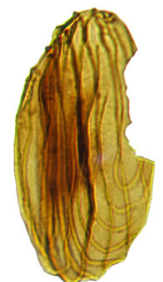

14

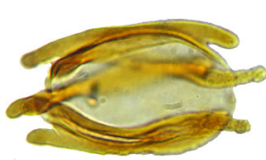

18

2

6

10
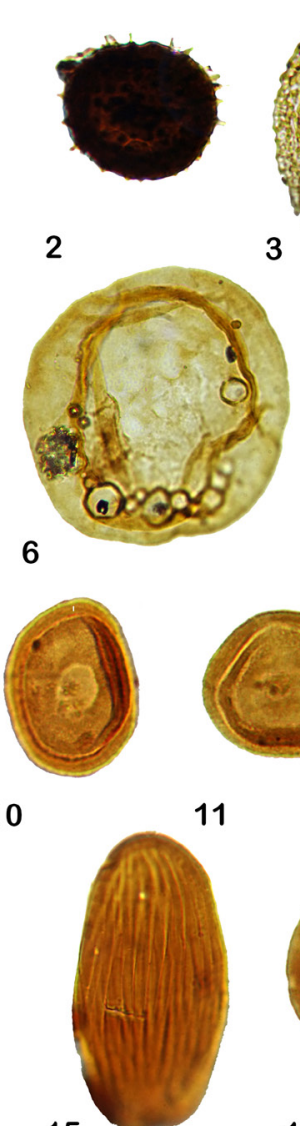

15

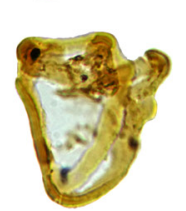

19

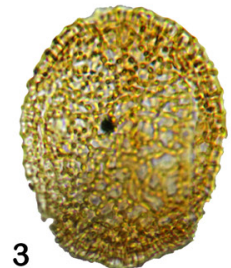

4
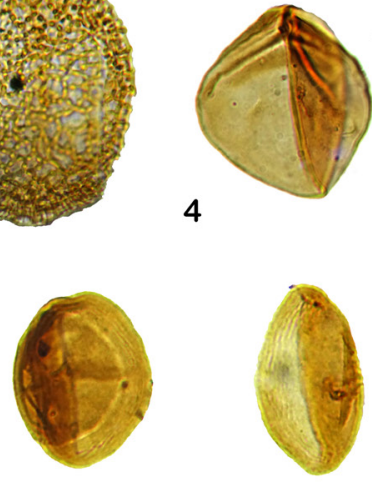

7
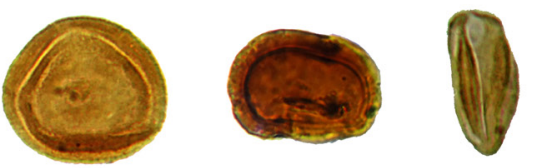

12

13

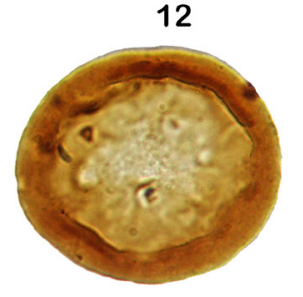

16

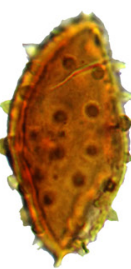

17
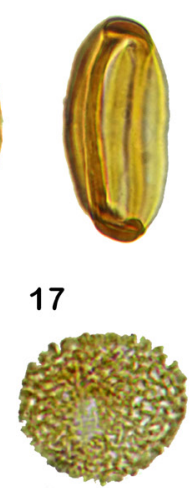

21

Plate II.

II.1 Leptolepidites psarosus Norris; B-1 3117/1; N39/1-2; $20 \mu \mathrm{m}$.

II.2 Pilosisporites trichopapillosus (Thiergart) Delcourt and Sprumont; B-1 3117/1; R34/3; $19 \mu \mathrm{m}$.

II.3 Schizosporis reticulatus Cookson and Dettmann emend. Pierce; B-1 3105/1; P18/3-4; $21 \mu \mathrm{m}$.

II.4 Triplanosporites sp.; B-1 3105/1; H55; $20 \mu \mathrm{m}$.

II.5 Undulatisporites pannuceus (Brenner) Singh; B-1 3117/3; J67/2-4; $18 \mu \mathrm{m}$.

II.6 Araucariacites australis Cookson ex Couper; B-1 3105/1; P55/2; $23 \mu \mathrm{m}$.

II.7 Classopollis brasiliensis Herngreen; B-1 3105/1; T57/3-4; $15 \mu \mathrm{m}$.

II.8 Classopollis brasiliensis Herngreen; B-1 3117/1; T20/2; $16 \mu \mathrm{m}$.

II.9 Classopollis classoides Pflug emend. Pocock and Jansonius; B-1 3105/1; L53/2-4; $19 \mu \mathrm{m}$.

II.10 Classopollis torosus (Reissinger) Couper; B-1 3105/2; R49/1; $15 \mu \mathrm{m}$.

II.11 Classopollis cf. triangulus (Zhang) Lei; B-1 3105/2; F43/1; $16 \mu \mathrm{m}$.

II.12 Circulina parva Brenner; B-1 3117/1; R24/3; $15 \mu \mathrm{m}$.

II.13 Eucommiidites troedssonii (Erdtman) Hughes; B-1 3105/1; M55/3; $13 \mu \mathrm{m}$.

II.14 Ephedripites jansonii (Pocock) Muller; B-1 3117/1; G29/1-3; $23 \mu \mathrm{m}$.

II.15 Ephedripites regularis van Hoeken-Klinkenberg; B-1 3105/1; G15/2-4; $22 \mu \mathrm{m}$.

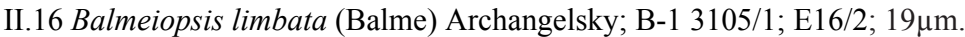

II.17 Steevesipollenites cupuliformis Azéma and Boltenhagen; B-1 3105/1; X18; $17 \mu \mathrm{m}$.

II.18 Elaterosporites klaszii (Jardiné and Magloire) Jardiné; B-1 3105/2; F18; $17 \mu \mathrm{m}$.

II.19 Indetermined elaterate pollen; B-1 3105/2; S51; $20 \mu \mathrm{m}$.

II.20 Echinomonocolpites sp.; B-1 3105/2; P31/1-2; $18 \mu \mathrm{m}$.

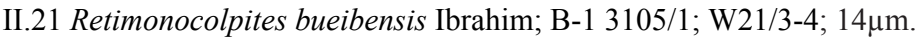



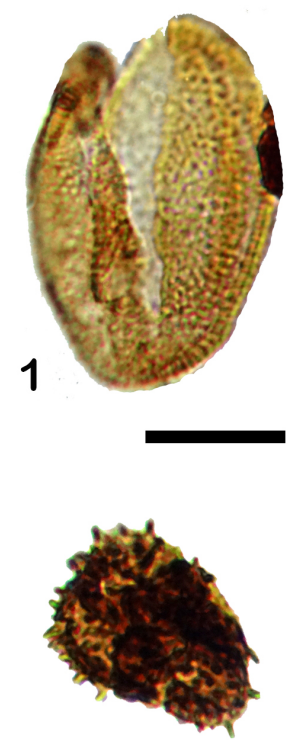

5

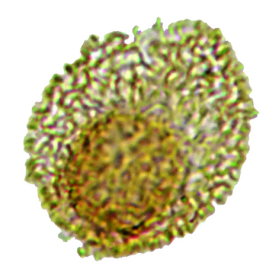

9

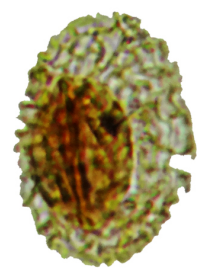

13

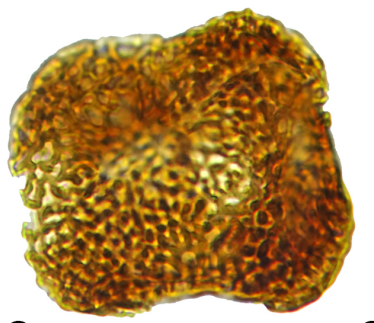

2

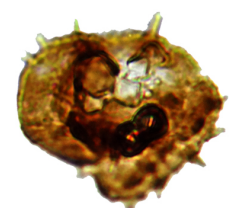

6

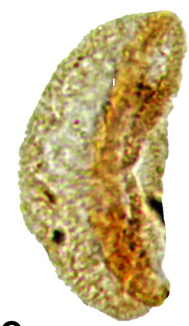

10

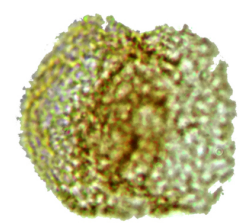

14

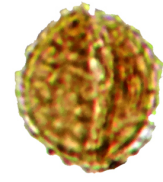

15
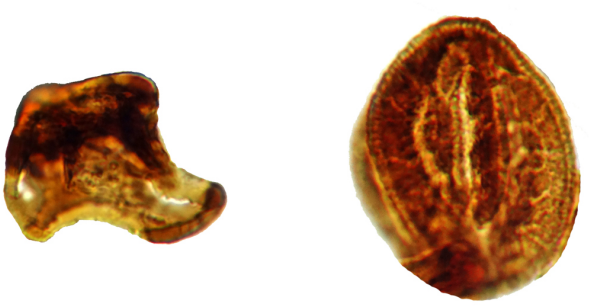

3

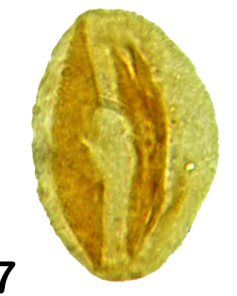

8
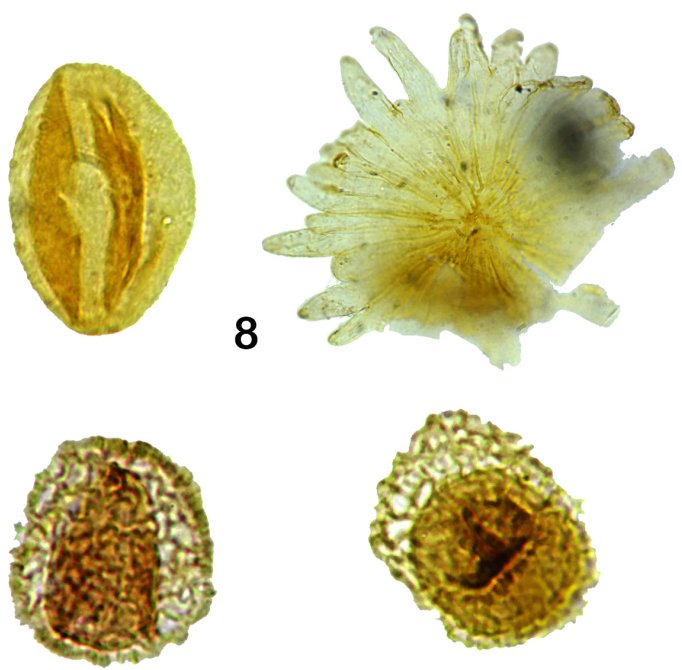

11

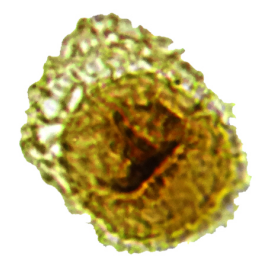

12

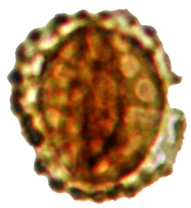

16

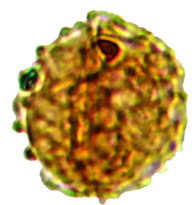

17

Plate III.

III.1 Retimonocolpites variplicatus Schrank and Mahmoud; B-1 3105/1; E42/3-4; $18 \mu \mathrm{m}$.

III. 2 Cretacaeiporites densimurus Schrank and Ibrahim; B-1 3105/1; W36/3-4; $23 \mu \mathrm{m}$.

III.3 Cretacaeiporites polygonalis (Jardiné and Magloire) Herngreen; B-1 3105/1; N50/4; $13 \mu \mathrm{m}$.

III.4 Foveotricolpites gigantoreticulatus (Jardiné and Magloire) Schrank; B-1 3105/2; K44/1-3; $17 \mu \mathrm{m}$.

III.5 Droseridites baculatus Ibrahim; B-1 3117/3; M67/2-4; 15 $\mu \mathrm{m}$.

III.6 Droseridites senonicus Jardiné and Magloire; B-1 3105/2; N28/1; $22 \mu \mathrm{m}$.

III.7 Tricolpites sp. (equatorial view); B-1 3105/1; K52/3-4; $18 \mu \mathrm{m}$.

III.8 Peltate hair of a flowering plant (may be recent contamination); B-1 3105/4; E50/3; $42 \mu \mathrm{m}$.

III.9 Afropollis jardinus (Brenner) Doyle et al.; B-1 3105/1; O47/2-4; 14 $\mu \mathrm{m}$.

III.10 Afropollis kahramanensis Ibrahim and Schrank; B-1 3105/1; G49/1-2; $15 \mu \mathrm{m}$.

III.11 Afropollis operculatus Doyle et al.; B-1 3105/1; P31/3-4; $14 \mu \mathrm{m}$.

III.12 Afropollis operculatus Doyle et al.; B-1 3117/1; J30/1-3; $14 \mu \mathrm{m}$.

III.13 Afropollis schrankii Ibrahim; B-1 3105/1; N54/2; 14 $\mu \mathrm{m}$.

III.14 Afropollis zonatus Doyle et al.; B-1 3105/1; B44/4; $19 \mu \mathrm{m}$.

III.15 Brenneripollis peroreticulatus (Brenner) Juhász and Góczán; B-1 3117/3; M66/1-3; $12 \mu \mathrm{m}$.

III.6 Brenneripollis reticulatus (Brenner) Juhász and Góczán; B-1 3117/1; J36/3-4; $12 \mu \mathrm{m}$.

III.17 Brenneripollis reticulatus (Brenner) Juhász and Góczán; B-1 3117/1; J21/1; $12 \mu \mathrm{m}$. 


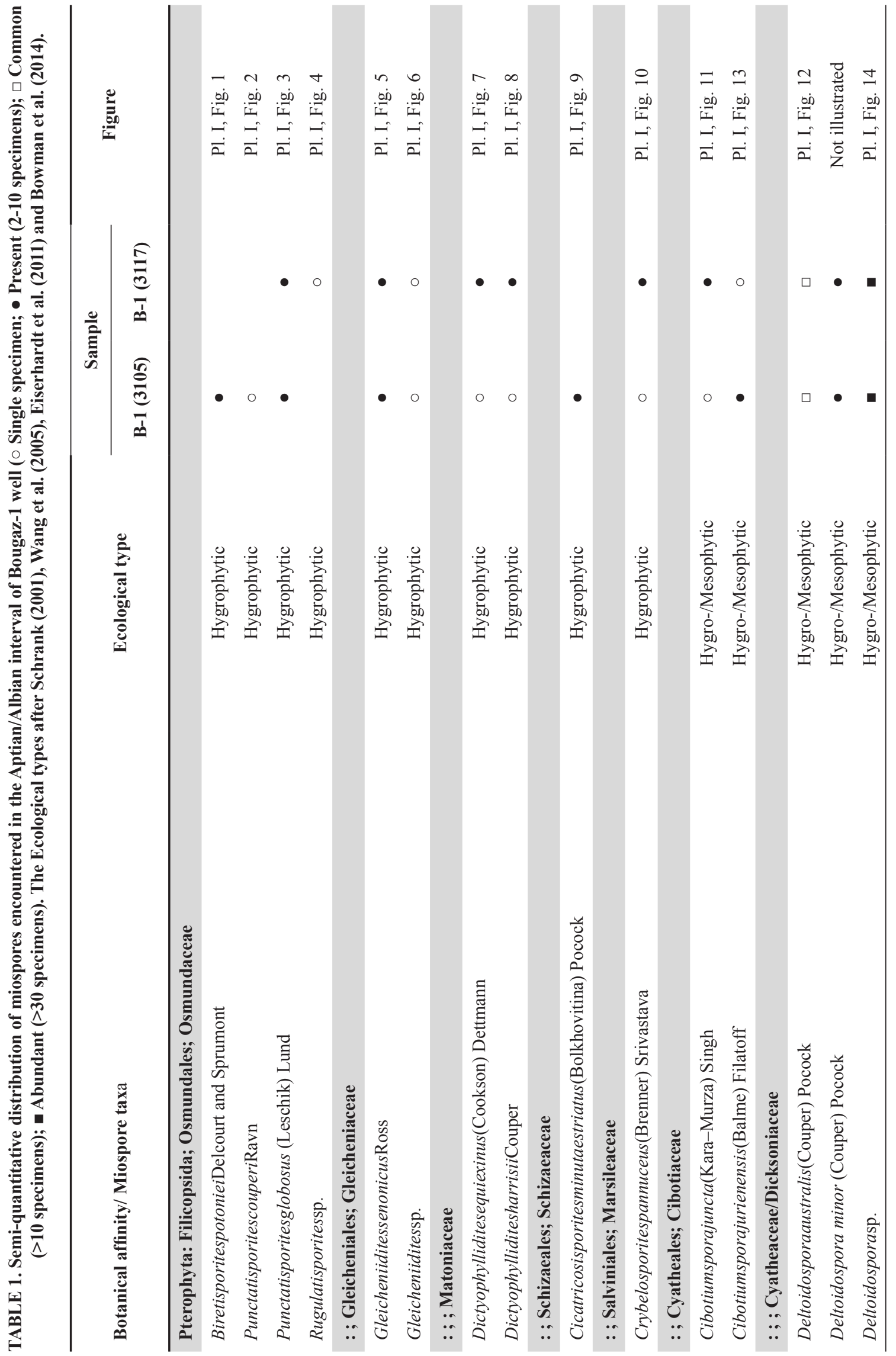

Egypt. J. Bot. 58, No.3 (2018) 


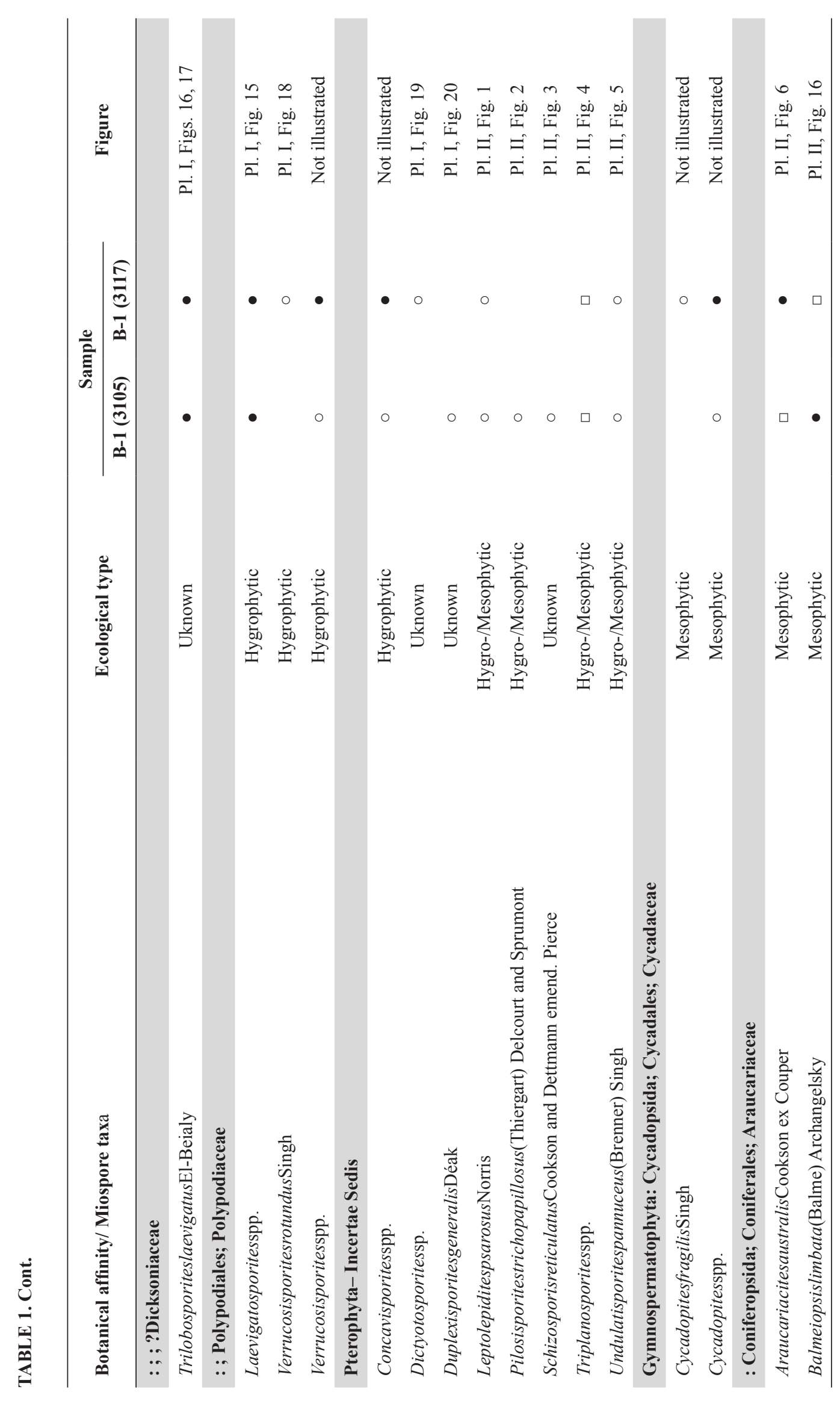

Egypt. J. Bot. 58, No. 3 (2018) 


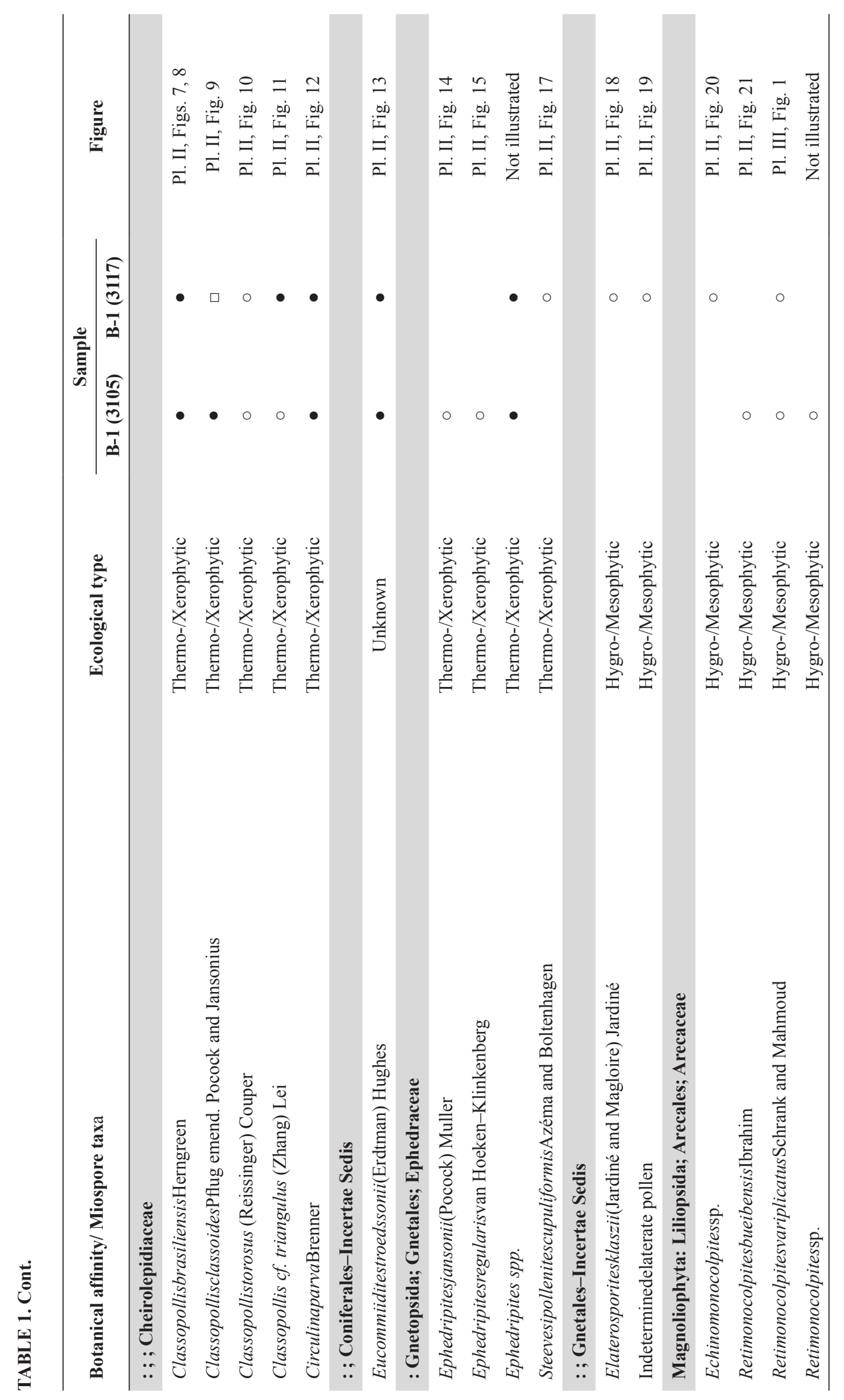

Egypt. J. Bot. 58, No.3 (2018) 


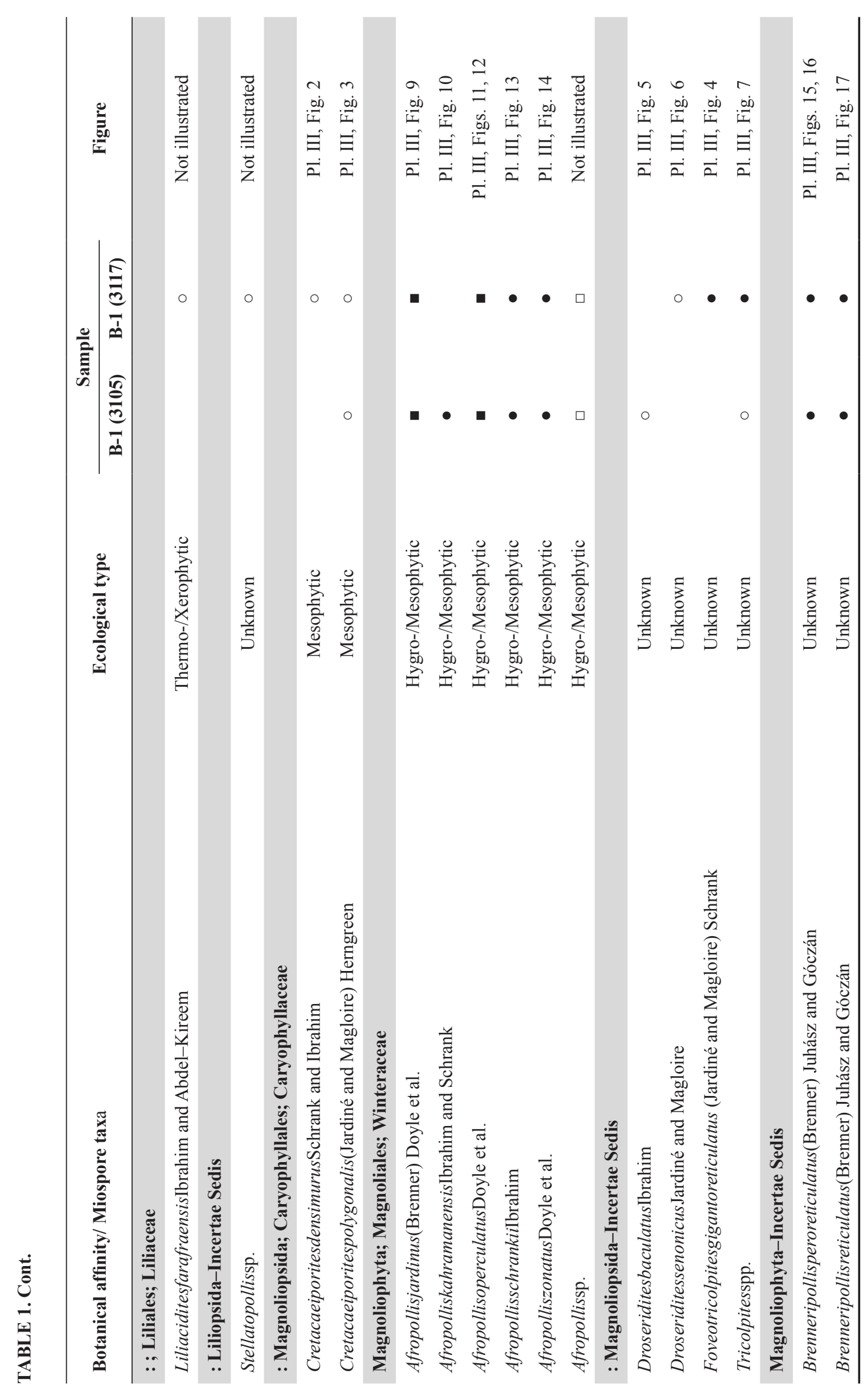

Egypt. J. Bot. 58, No. 3 (2018) 
Ferns

The present palynological assemblage shows a predominance of ferns (average $47 \%$ of the total sporomorph assemblage). Several subordinate families can be deduced, including Osmundaceae (Biretisporites, Punctatisporites \& Rugulatisporites), Gleicheniaceae (Gleicheniidites), Matoniaceae (Dictyophyllidites), Schizaeaceae (Cicatricosisporites), Marsileaceae (Crybelosporites), Cibotiaceae (Cibotiumspora), Cyatheaceae/Dicksoniaceae (Deltoidospora)? Dicksoniaceae (Trilobosporites) and Polypodiaceae (Laevigatosporites \& Verrucosisporites). Among them, Cyatheaceae/ Dicksoniaceae is dominant, Gleicheniaceae and Matoniaceae occur less frequently. The Osmundaceae, Schizaeaceae, Marsileaceae, Cibotiaceae,? Dicksoniaceae and Polypodiaceae are rare. Besides, other genera (Concavisporites, Dictyotosporites, Duplexisporites, Leptolepidites, Pilosisporites, Schizosporis, Triplanosporites, Undulatisporites) which are related to the early Pterophyta but their botanical position cannot yet be ascertained. The latter genera are rare except Triplanosporites which is highly represented $(17 \%)$, in the present assemblage.

\section{Angiosperms}

Angiosperm pollen group generally occurs as a subordinate element in the present assemblage (average $31.5 \%$ of the total sporomorph assemblage). It is characterized by abundance of Afropollis which is thought to be in the Winteraceae. Other minor contributors are of the Arecaceae (Echimonocolpites \& Retimonocolpites), Liliaceae (Liliacidites), Caryophyllaceae (Cretacaeiporites), an undifferentiated tetrad and tricolpate monosulcate pollen of unknown angiospermic origin.

\section{Gymnosperms}

Gymnosperm pollen occurs as a minor element with average of $21.5 \%$ of the total sporomorph assemblage. It is represented by a mixture of conifers, Cycadopsida and Gentopsida. Conifers are the most dominant category of the gymnosperms which are represented by Araucariaceae (Araucariacites \& Balmeiopsis), Cheirolepidiaceae (Classopollis \& Circulina) and undifferentiated aperturate pollen (Eucommidites) produced by an unknown family of Coniferales. The Cycadopsida and Gentopsida generally occur less frequently. Cycadopites is the only identified genus with affinity to Cycadaceae. The polyplicate pollen (Ephedripites \& Steevesipollenites) and elaterate pollen (Elaterosporites), which are botanically related, are thought to be of gnetalean origin.

\section{Palaeoclimatic implications}

Terrestrial plants are more climatically sensitive than most marine organisms. They have specific demands of temperature, moisture and soil. Consequently, this makes it possible to interpret the palaeoclimate conditions that were prevailing during their life cycles from their sporomorph assemblages preserved in the sediments (Wang et al., 2005).

The paleoecologic and paleoclimatic interpretation of Cretaceous pollen and spore assemblages often relies on the overall composition of the floras because the nearest living relatives at the specific or generic level are not available (Schrank \& Nesterova, 1993).

In the presnt palynoassemblage many taxa seem to have local palaeoclimate and ecological preferences. In order to track these trends, the relative abundances of the encountered miospores and the hygric types of their modern analogues (hygrophytic, mesophytic, hygro-mesophytic and thermophytic/xerophytic) are summarized in Table 1.

The Aptian/Albian vegetation in Bougaz Basin is characterized by the high relative abundance and diversity of hygrophilous and hygro-mesophilous fern spores belonging to Osmundaceae, Gleicheniaceae, Matoniaceae, Schizaeaceae, Marsileaceae, Cibotiaceae, Cyatheaceae/Dicksoniaceae,? Dicksoniaceae and Polypodiaceae, among others of unknown botanical affinities, which indicates humid conditions comparable with the majority of the extant hygro-mesophilous ferns, which prefer to grow in warm humid lowlands such as riversides or as understory in forests (Pelzer et al., 1992 and Abbink et al., 2004). Similar ecological preferences are also confirmed by the relatively high abundance of Afropollis a pollen of winteraceaen affinity which was proposed to inhabit paleotropical humid coastal plains (Schrank, 2001).

According to Doyle et al. (1982), the relatively low abundances of Mesozoic conifer families such as Araucariaceae which have mesic 
preferences and Cheirolepidiaceae which have inhabited relatively dry areas of upland forest are used as palaeo-indicators of hot dry conditions (i.e., thermo-/xerophytic forms). Further support of the prevalence of more humid conditions, agreed with Doyle et al. (1982), Schrank (1990) and Brenner (1996) who suggested relatively wetter paleoclimates for African paleotropics (e.g. Egypt and Sudan), based on the presence of high abundances of fern spores (indicating humidity) and lower frequencies of Classopollis and the cooler-temperate coniferous genus Araucariacites than seen in the paleosubtropics.

The gymnospermous genetalean pollen Ephedripites is another xerophytic genus. Its rarity in the studied interval could also suggest less hot and more humid conditions, as its high abundances are taken to indicate hot and dry conditions (Doyle et al., 1982 and Dino et al., 1999).

The hot and relatively wetter paleoclimate that is suggested to prevail during the Early Cretaceous over the Egyptian land area is also compatible with such a deduction driven from the paleolatitudinal position. During this time, Egypt was continuously located at the paleotropical zone where hot but relatively wetter conditions prevailed due to the highest rainfall rate at or near the paleoequator (Dino et al., 1999).

\section{Conclusion}

The sporomorph assemblage recovered from two studied samples of Cretaceous (Aptian/ Albian) shales from Bougaz-1 well in northeast Sinai consists of 39 genera and 62 species of miospores. A reconstruction of the vegetation showed a mixed forest of three distinct plant groups. In order of dominance, pteridophytic ferns represent the most abundant group (47\%), followed by angiosperms (31.5\%) and gymnosperms (21.5\%). The distribution of hygrophilous versus xerophytic elements in the present assemblage is used to interpret the paleoclimatic trends in this part of Egypt during Aptian/Albian period. A relatively warm humid climate is proposed based on the high frequency and diversity of pteridophytic fern spores together with relative abundances of Afropollis pollen which are usually regarded as indicative of humid conditions. This interpretation is also supported by the low frequency of conifer vegetation such as Araucariaceae, Cheirolepidiaceae and genetalean pollen (Ephedripites) which are indicative of semi-arid/arid conditions.

Acknowledgment: The author expresses her gratitude to the authorities of the Egyptian General Petroleum Corporation (EGPC) for providing the samples for this study.

\section{References}

Abbink, O.A., van Konijnenburg-van Cittert, J.H.A. and Visscher, H. (2004) A sporomorph ecogroup model for the Northwest European Jurassic-Lower Cretaceous: concepts and framework. Netherlands Journal of Geosciences/Geologie en Mijnbouw, 83, 17-38.

Abdel-Kireem, M.R., Schrank, E., Samir, A.M. and Ibrahim, M.I.A. (1996) Cretaceous palaeoecology, palaeogeography and palaeoclimatology of the northern Western Desert. Egypt Journal of African Earth Sciences, 22(1), 93-112.

Arnold, C.A. (1969) The fossil-plant record. In: "'Aspects of Palynology", Tschudy, R.H. and Scott, R.A. (Ed.), pp. 127-143, Wiley-interscience.

Bowman, V., Francis, J.E., Askin, R.A., Riding, J.B. and Swindles, G.T. (2014) Latest Cretaceous earliest Paleogene vegetation and climate change at the high southern latitudes: Palynological evidence from Seymour Island, Antarctic Peninsula. Palaeogeography, Palaeoclimatology, Palaeoecology, 408, 26-47.

Brenner, G.J. (1963) The spores and pollen of the Potomac Group of Maryland. Maryland Department of Geology, Mines and Water Resources Bulletin, 17, 1-215.

Brenner, G.J. (1996) Evidence for the earliest stage of Angiosperm pollen evolution: A paleoequatorial section from Israel. In: "Flowering Plant Origin, Evolution, and Phylogeny", Taylor, D.W., Hickey, L.J. (Ed.), pp. 91-115. Chapman and Hall, New York.

Couper, R.A. (1958) British Mesozoic microspores and pollen grains. A Systematic and Stratigraphic Study. Palaeontographica B, 103, 75-179.

Dettmann, M.E. (1963) Upper Mesozoic microfloras from south-eastern Australia. Proceedings of the Royal Society of Victoria, 77(1), 1-148. 
Dino, R., Pocknall, D.T. and Dettmann, M.E. (1999) Morphology and ultrastructure of elater-bearing pollen from the Albian to Cenomanian of Brazil and Ecuador: Implications for botanical affinity. Review of Palaeobotany and Palynology, 105, 201-235.

Doyle, J.A., Jardiné, S. and Doerenkamp, A. (1982) Afropollis, a new genus of early angiosperm pollen, with notes on the Cretaceous palynostratigraphy and palaeoenvironments of northern Gondwana. Bulletin des centres de Recherche Exploration-Production Elf-Aquitaine, 6(1), 39-117.

Eiserhardt, W.L., Svenning, J., Kissling, W.D. and Balslev, H. (2011) Geographical ecology of the palms (Arecaceae): Determinants of diversity and distributions across spatial scales. Annals of Botany, 108, 1391-1416.

El Noamani, Z.M. and Saleh, A.I. (2018) Cretaceous algal palynomorphs from northeast Sinai, Egypt: Systematics and paleoenvironmental implications. Egyptian Journal of Botany, 58(1), 63-72.

Felix, C.J. and Burbridge, P.P. (1973) A Maestrichtian age microflora from Arctic Canada. Geoscience and Man, II, 1-29.

Ibrahim, M.I.A., Zobaa, M.K., El Noamani, Z.M. and Tahoun, S.S. (2017) A review of the angiosperm pollen genus Cretacaeiporites Herngreen, with one new species from the Upper Cretaceous of Egypt. Palynology, 41(1), 101-116.

Kedves, M. (1986) Etudes palynologiques sur les sediments préquaternaires de L'Egypt Eocene. Revista Española de Micropaleontología, 18, 5-26.

Krassilov, V. and Schrank, E. (2011) New Albian macro- and palynoflora from the Negev (Israel) with description of a new gymnosperm morphotaxon. Cretaceous Research, 32(1), 13-29.

Mahmoud, M.S. and Schrank, E. (2007) Late Cretaceous spores, pollen and dinoflagellates from two boreholes (Nuqra-1 and 3) in the Aswan area, southeast Egypt. Revue de Paléobiologie, Genève, 26(2), 593-613.

Mohr, B.A.R. and Gee, C.T. (1992) An early Albian palynoflora from the Kerguelen Plateau, southern Indian Ocean (Leg 120). In: Proceedings of the Ocean Drilling Program, Scientific Results, College Station, TX (Ocean Drilling Program),Wise, S.W. Jr., Schlich, R. et al. (Ed.), pp. 255-271.
Narváez, P.L. and Sabino, I.F. (2008) Palynology of the Las Curtiembres Formation (Late Cretaceous, Salta Group Basin), Las Conchas Creek area, Northwestern Argentina. Ameghiniana, 45(2), 473482.

Pelzer, G., Riegel, W. and Wilde, V. (1992) Depositional control on the lower Cretaceous Wealden coals of Northwest Germany. Geological Society of America, Special paper, 267, 227-243.

Pole, M. and Vajda, V. (2009) A new terrestrial Cretaceous-Paleogene site in New Zealand-turnover in macroflora confirmed by palynology. Cretaceous Research, 30, 917-938.

Ravn, R.L. (1995) Miospores from the Muddy Sandstone (upper Albian), Wind River Basin, Wyoming, U.S.A. Palaeontographica, B 234, 41-91.

Saad, S.I. (1963) Pollen and spores recently discovered in the coals of Sinai region. I. Euone Moussa district. Palaeontographica, B 113, 117-125.

Saad, S.I. (1965) Pollen and spores recently discovered in the coals of Sinai region. II. Um Bogma district. Palaeontographica, B 115, 139-149.

Saad, S.I. (1974) Palynological results and their bearing on the theory of continental displacement. Advances in Pollen-Spore Research, 1, 70-77.

Saad, S.I. (1978) Palynological studies in the Egyptian Western Desert, Umbarka $1 \mathrm{X}$ borehole. Pollen et Spores, 20(2), 261-301.

Scafati, L., Melendi, D.L. and Volkheimer, W. (2009) A Danian subtropical lacustrine palynobiota from South America (Bororó Formation, San Jorge Basin, Patagonia- Argentina). Geologica Acta, 7(12), 35-61.

Schrank, E. (1990) Palynology of the clastic Cretaceous sediments between Dongola and Wadi Muqaddam, northern Sudan. Berliner geowissenschaftliche Abhandlungen Reihe, A 120(1), 149-168.

Schrank, E. (2001) Palaeoecological aspects of Afropollis/Elaterates peaks (Albian-Cenomanian pollen) in the Cretaceous of northern Sudan and Egypt. In: Proceedings of the IX International Palynological Congress. Goodman, D.K., Clarke, R.T. (Ed.). Houston, Texas, USA, 1996. AASP Foundation, pp. 201-210. 
Schrank, E. and Mahmoud, M.S. (2002) Barremian angiosperm pollen and associated palynomorphs from Dakhla Oasis area, Egypt. Palaeontology, 45(1), 33-56

Schrank, E. and Nesterova, E.V. (1993) Palynofloristic changes and Cretaceous climates in northern Gondwana (NE Africa) and southern Laurasia (Kazakhstan). In: "Geoscientific Research in Northeast Africa". Thorweihe, U., Schandelmeier, H. (Ed.), pp. 381-390. Balkema, Rotterdam.

Singh, C. (1964) Microflora of the Lower Cretaceous Mannville Group, East-Central Alberta. Alberta Research Council Bulletin, 15, 1-239.

Singh, C. (1971) Lower Cretaceous microfloras of the Peace River area, northwestern Alberta. Alberta Research Council Bulletin, 28, 1-542.

Srivastava, S.K. (1977) Microspores from the Fredericksburg Group (Albian) of the southern United States. Paleobiologie Continentale, 6(2), $1-119$.

Srivastava, S.K. and Binda, P.L. (1991) Depositional history of the early Eocene Shumaysi Formation, Saudi Arabia. Palynology, 15(1), 47-61.
Takahashi, K. and Suciyama, R. (1990) Palynomorphs from the Santonian Uge member of the Taneichi formation, Northeast Japan. Bulletin of the Faculty of Liberal Arts, Nagasaki University, Natural Science, 30(2), 133-573.

Villalba-Breva, S., Martín-Closas, C., Marmi, J., Gomez, B. and Fernández-Marrán, M.T. (2012) Peat-forming plants in the Maastrichtian coals of the Eastern Pyrenees. Geologica Acta, 10(2), 189-207.

Wang, Y.D., Moshrugger, V. and Zhang, H. (2005) Early to Middle Jurassic vegetation and climatic events in the Qaidam Basin, Northwest China. Palaeogeography, Palaeoclimatology, Palaeoecology, 224, 200-216.

Wingate, F.H. (1980) Plant microfossils from the Denton Shale Member of the Bokchito Formation (Lower Cretaceous, Albian) in southern Oklahoma. Oklahoma Geological Survey Bulletin, 130, 1-93.

(Received 10/ 2 /2018; accepted 8 / 5 /2018)

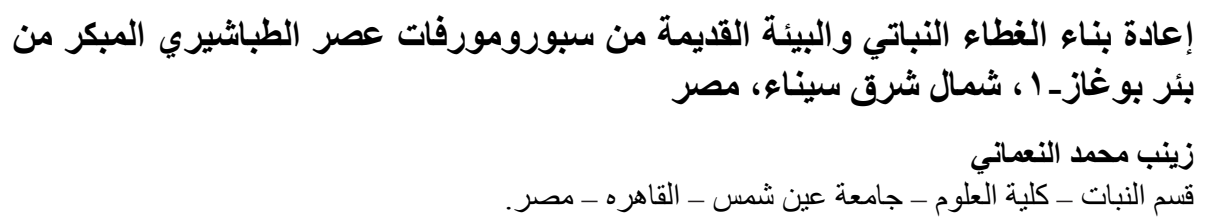

من دراسة المحتوي الأحفوري (حبوب اللقاح والأبواغ) في تتابع الطباثبيري السفلي (الأبتي/الألبي) ببئر

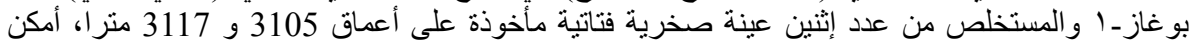

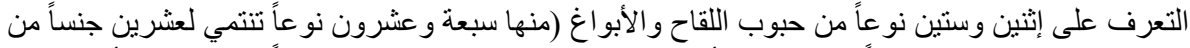

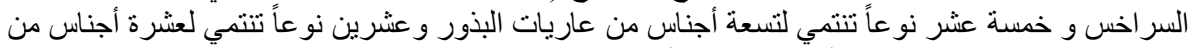

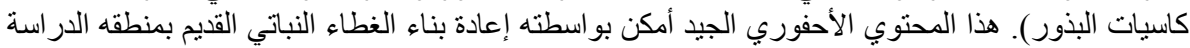

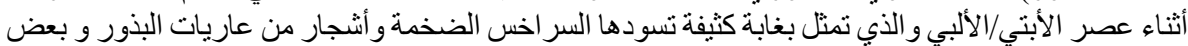

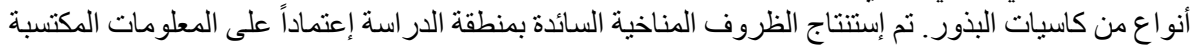

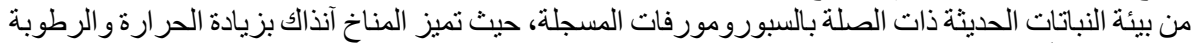

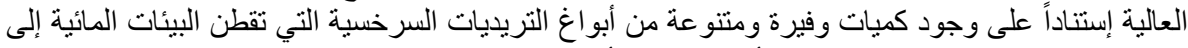

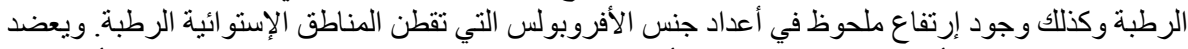

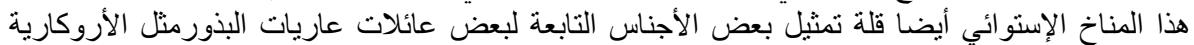

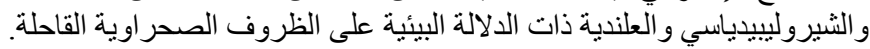

